\title{
How long does it take for tropical marine fish stocks to recover after declines? Case studies from the Southwest coast of India
}

\author{
K. S. Mohamed* and S. Veena ${ }^{1}$ \\ Central Marine Fisheries Research Institute, PO Box 1603, Kochi 682 018, India \\ ${ }^{1}$ Present address: Mangalore Research Centre of Central Marine Fisheries Research Institute, PO Box 244, Mangalore 575 001, India
}

\begin{abstract}
The depletion/collapse and recovery of tropical marine fish stocks have been studied by deriving the time-series of stock status of commercially fished marine species in Karnataka. Majority of stocks $(22$ out of 47) showed wide fluctuations in catch whereas 15 stocks were dwindling. This analysis of catch trends (as a simple proxy for biomass estimates) shows that, in spite of consistently increasing efforts and absence of many regulatory measures, most species $(66 \%)$ had fast recovery capacity within $1-5$ years whereas $9 \%$ were slow to recover. The depleted and declining stocks need to be carefully monitored and conservation and rebuilding plans need to be made.
\end{abstract}

Keywords: Arabian Sea, fluctuating and dwindling stocks, Karnataka, recovery after decline, tropical marine fish stocks.

SEVERE habitat loss and population declines of species have occurred in the oceans, leading to concerns that populations or species may be at risk of extinction over large spatial scales ${ }^{1-3}$. Fishermen are switching to new fish species as traditional ones are diminishing, sometimes to vanishing point ${ }^{4}$. Small-scale fisheries that employ $98 \%$ of the world's fishers ${ }^{5}$ and land more than half the world's annual marine catch ${ }^{6}$ are poorly understood because there are little formal surveys or monitoring of exploitation. There is practical difficulty in measuring the point at which a taxon becomes extinct, particularly in the sea $^{2,3,7}$. Generally in an ecosystem, diversity is dominated by a few common species followed by multiple rare species. As environments become disturbed, the dominance of the core community usually becomes more pronounced, and rarer species are no longer able to survive $^{8,9}$.

A growing online database of worldwide fisheries research is helping scientists better understand the relationship between managing fishing pressures and restoring depleted fish stocks ${ }^{10}$. Jensen ${ }^{11}$ noted that threequarters of 62 depleted stocks worldwide continue to be fished at intensities too great to allow populations to

*For correspondence. (e-mail: ksmohamed@gmail.com) recover. There is very little evidence for rapid recovery from prolonged (15 year) declines ${ }^{12}$, and fish stocks which are resilient may recover from overfishing, but only if the harvesting stops at the first sign of depletion. If the overfishing goes on for too long, the stocks may never recover ${ }^{13}$. Over the past decades, an increasing number of studies have reported recoveries of depleted marine populations and degraded ecosystems and there have been significant advances in understanding recoveries in the ocean ${ }^{14}$. Stricter management and improved governance have enabled the rebuilding of some fish populations, whereas others remain in low numbers ${ }^{15,16}$. Exploitation rate which is the ultimate driver of depletion and collapse, if decreased, helps in management of the fisheries, setting the stage for ecological and economic recovery ${ }^{17}$. Recovery occurs in more than $10 \%$ but less than $50 \%$ of species or ecosystems, suggesting a need for improved management and conservation ${ }^{14}$.

Marine fisheries and seafood industry are recognized as key industries in India showing an average growth rate of $6.4 \%$ over a period of 5 decades ${ }^{18}$. Mechanization increased by $57 \%$ between 1960 and 1990 contributing to a situation of overcapacity and resultant overfishing ${ }^{19}$. The recent trend in unregulated increase in net sizes and declining of mesh size is not healthy considering the increasing capture of juveniles ${ }^{20,21}$. Recently, the status of marine fish stocks of Kerala and Karnataka (Southwest coast of India) has been studied and categorized into abundant, less abundant, developing, declining and collapsed $^{22}$, with the assumption that catch is proportional to abundance and historical maximum catch being the baseline data. The same methodology has been applied to make assessments of 26 resource groups (pelagics, demersals, crustaceans, molluscs) on a national basis and it indicated that nearly $90 \%$ of the resource groups fall under the 'abundant' and 'less abundant' class whereas the remaining under the 'declining', 'depleted' and 'collapsed' classes ${ }^{23}$. For resources that are depleted, recovery is expected to be long and not guaranteed ${ }^{24}$. However, there are few studies ${ }^{25}$ documenting such recoveries from the tropical world.

Karnataka is one of the frontline states of India in marine fisheries development ${ }^{26}$, contributing 6-14\% 
annually to the total marine fish production of India. It has a short coast line of $300 \mathrm{~km}$, continental shelf area of $27,000 \mathrm{sq} . \mathrm{km}$ and 87,000 sq. $\mathrm{km}$ of exclusive economic zone (EEZ), within $12^{\circ} 45^{\prime} \mathrm{N}$ and $14^{\circ} 95^{\prime} \mathrm{N}$ and $73^{\circ} 45^{\prime} \mathrm{E}$ and $74^{\circ} 95^{\prime} \mathrm{E}$. The state has three coastal districts, Dakshina Kannada, Udupi and Uttara Kannada, and more than 90\% of the state's marine fish production comes from the major fishing ports of Mangalore in Dakshina Kannada district, Malpe in Udupi district and Kasargode/ Honnavar, Tadri and Karwar in the Uttara Kannada district. These centres cater almost exclusively to the mechanized fishing sector and the non-mechanized artisanal gears are mainly concentrated in the northern regions (Uttara Kannada district), whereas mechanized (outboard engines) artisanal gears are in vogue in the southern regions (Dakshina Kannada and Udupi districts $)^{27}$. This state has been a pioneer in the introduction of new mechanized fishing technologies, development of fishing harbours and improvement in the living standards of fishermen ${ }^{26}$. The mechanization caused steep increase in total yields in all fleets in the fishery in the seventies and eighties ${ }^{28}$ followed by downtrend due to overfishing. The production peaked again in 2002 and had stabilized to 192,816 tonnes in 2004 (ref. 29) after which it has increased to more than 437,000 tonnes in recent years 2013-14 (ref. 30).

The collapse and recovery of tropical marine fish stocks has not been well studied before mainly because of lack of complete time-series on actual biomasses which are expensive to collect. Because catch assessments are an indirect estimate of biomass in the sea, Mohamed et $a l^{22}$ developed the rapid fish stock classification method. In this analysis, we transform the fish stock classification from a single snap-shot assessment to a continuous yearly assessment and see how tropical fish stocks change from one category to another. If the stock is depleted or collapsed, we assess the number of years it takes for the stock to regain an abundant status.

\section{Materials and methods}

The records containing species-wise and gear-wise catch and effort of marine fish landings of Karnataka (period 1971-2008) maintained by the Central Marine Fisheries Research Institute (CMFRI), Kochi, India in National Marine Fisheries Data Centre were used for the present study. The CMFRI estimates marine fish catch and effort from all along the Indian coast based on a stratified multi-stage random sampling design with the stratification over space and time ${ }^{31}$. These data (37 years) were collected by trained enumerators, who could identify fished organisms to the species level in most cases. The non-standardized effort data in fishing hours from 14 different gears were aggregated and plotted on a yearly basis to delineate the trend in fishing effort.
From the list of 47 common species, the stock status (abundant, less abundant, declining, depleted and collapsed) was determined by comparing the historical maximum catch with its recent average catch during 2006-2008 (3 years) using the criteria developed by Mohamed et $a l^{22}$. A caveat of this method is that the stock status is not based on actual biomasses.

Yearly stock status was derived by using the same method, but instead of a recent 3-year average catch, a 3 -year moving average for 37 years was considered. In this manner, the stock status of all species considered could be derived for every year of the period according to the above criteria. Based on the behaviour of the resulting plots, the species were grouped as developing, fluctuating and dwindling. The year during which the species was depleted/collapsed and the duration taken for their recovery to abundance were then tabulated. The species/stocks which were in the dwindling group were placed in respective taxonomic families and the average years taken by each family were derived.

\section{Results}

From the list of 47 common species, the stock status of the species was generated and it showed that $12(25.5 \%)$ species were abundant, 5 (10.6\%) were less abundant, 25 $(53.2 \%)$ were declining, 2 were depleted and 3 were collapsed (Figure 1 and Table 1). The two depleted stocks were the white sardine Escualosa thoracata and giant tiger shrimp Penaeus monodon and the three collapsed stocks were the flathead Sunagocia indicus, the catfish Arius sp. and blacktip shark Carcharhinus sp. When the yearly stock status plots were generated, it showed that 22 species were fluctuating, 10 were developing and 15 species were dwindling.

All the species in the fluctuating group (Table 2 and Figure 2) have reached abundant status once or many

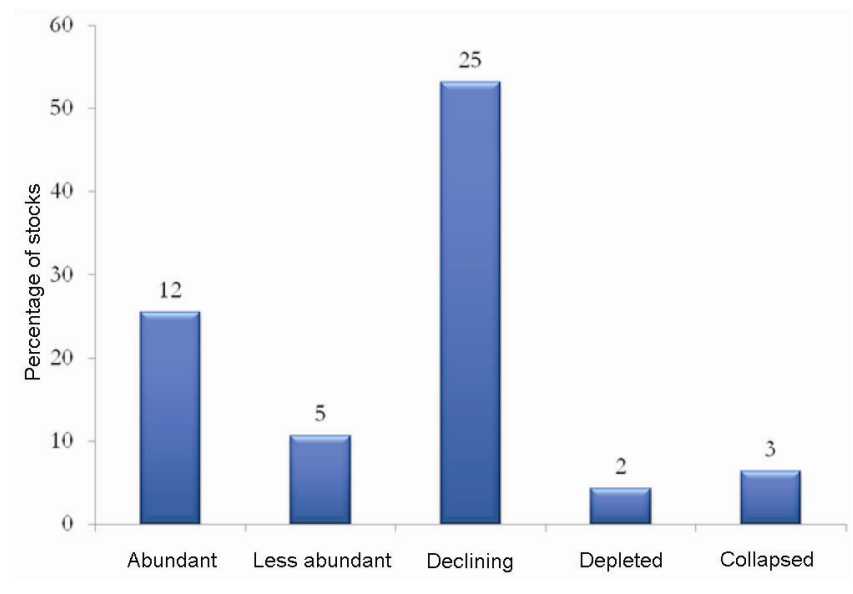

Figure 1. Percentage of marine fish stocks in Karnataka as per stockstatus classification. Actual numbers are shown above bars. 
Table 1. Most common marine species classified as abundant, less abundant, declining, depleted and collapsed based on comparison between average catch during 2006-08 (last 3 years) to that of the baseline catch in percentage of the historical maximum catch (1971-2005)

\begin{tabular}{|c|c|c|c|c|c|c|}
\hline Species/stock & Common name & $\begin{array}{l}\text { Historical } \\
\text { maximum } \\
\text { catch }(\mathrm{t})\end{array}$ & $\begin{array}{c}\text { Year of } \\
\text { historical } \\
\text { maximum catch }\end{array}$ & $\begin{array}{l}\text { Recent 3-year } \\
\text { average } \\
\text { catch }(\mathrm{t})\end{array}$ & $\begin{array}{l}\text { Percentage of } \\
\text { historical } \\
\text { maximum catch }\end{array}$ & Stock status \\
\hline Saurida sp. & Lizard fish & 3907 & 2001 & 10,027 & 256.7 & Abundant \\
\hline Sphyraena sp. & Barracuda & 1612 & 1995 & 2427 & 150.6 & Abundant \\
\hline Mugil cephalus & Flathead grey mullet & 128 & 1998 & 188 & 146.7 & Abundant \\
\hline Sepia sp. & Cuttlefish & 6328 & 2005 & 8501 & 134.3 & Abundant \\
\hline Nemipterus sp. & Threadfin bream & 21,630 & 2001 & 25,153 & 116.3 & Abundant \\
\hline Uroteuthis duvauceli & Indian squid & 8220 & 1989 & 7712 & 93.8 & Abundant \\
\hline Sardinella longiceps & Oil sardine & 85,915 & 1981 & 79,324 & 92.3 & Abundant \\
\hline Portunus pelagicus & Blue crab & 1057 & 1987 & 960 & 90.8 & Abundant \\
\hline Johnius sp. & Croaker & 3809 & 2005 & 3367 & 88.4 & Abundant \\
\hline Epinephelus sp. & Grouper & 6699 & 2002 & 4889 & 73.0 & Abundant \\
\hline Chirocentrus dorab & Wolf-herring & 548 & 1996 & 383 & 69.9 & Abundant \\
\hline Himantura sp. & Stingray & 237 & 1989 & 130 & 54.8 & Less abundant \\
\hline Parastromateus niger & Black pomfret & 3228 & 1995 & 1667 & 51.7 & Less abundant \\
\hline Sardinella fimbriata & Fringescale sardinella & 4072 & 1988 & 2091 & 51.3 & Less abundant \\
\hline Leiognathus sp. & Ponyfish & 7638 & 1986 & 3722 & 48.7 & Declining \\
\hline Cynoglossus macrostomus & Malabar tonguesole & 13,154 & 2000 & 6376 & 48.5 & Declining \\
\hline Lactarius lactarius & Whitefish & 4645 & 2001 & 2163 & 46.6 & Declining \\
\hline Portunus sanguinolentus & Three-spot swimming crab & 1365 & 2002 & 597 & 43.7 & Declining \\
\hline Pampus argenteus & Silver pomfret & 878 & 1974 & 372 & 42.4 & Declining \\
\hline Megalaspis cordyla & Horse mackerel & 8056 & 1986 & 3194 & 39.6 & Declining \\
\hline Euthynnus affinis & Kawakawa & 4177 & 1989 & 1620 & 38.8 & Declining \\
\hline Parapenaeopsis stylifera & Kiddi shrimp & 7332 & 1987 & 2727 & 37.2 & Declining \\
\hline Opisthopterus tardoore & Long-finned herring & 2231 & 2001 & 787 & 35.3 & Declining \\
\hline Anodontostoma chacunda & Chacunda gizzard shad & 567 & 1993 & 198 & 35.0 & Declining \\
\hline Sillago sihama & Lady fish & 244 & 1993 & 85 & 34.6 & Declining \\
\hline Hemiramphus sp. & Halfbeak & 700 & 1985 & 236 & 33.8 & Declining \\
\hline Metapenaeus dobsoni & Kadal shrimp & 8669 & 1987 & 2757 & 31.8 & Declining \\
\hline Fenneropenaeus merguiensis & Banana prawn & 253 & 1987 & 72 & 28.5 & Declining \\
\hline Otolithes sp. & Croaker & 1739 & 1994 & 487 & 28.0 & Declining \\
\hline Caranx sp. & Scads & 10,036 & 1988 & 2523 & 25.1 & Declining \\
\hline Thryssa sp. & Anchovy & 17,987 & 2005 & 4170 & 23.2 & Declining \\
\hline Stolephorus sp. & Anchovy & 11,959 & 1995 & 2646 & 22.1 & Declining \\
\hline Scomberomorus guttatus & Spotted seerfish & 3257 & 1981 & 574 & 17.6 & Declining \\
\hline Metapenaeus monoceros & Speckled shrimp & 15,890 & 1987 & 2343 & 14.7 & Declining \\
\hline Fenneropenaeus indicus & Indian white prawn & 12,853 & 2005 & 1866 & 14.5 & Declining \\
\hline Scoliodon laticaudus & Spadenose shark & 1975 & 1981 & 278 & 14.1 & Declining \\
\hline Scomberoides sp. & Queenfish & 896 & 1985 & 114 & 12.7 & Declining \\
\hline Escualosa thoracata & White sardine & 1533 & 1989 & 161 & 10.5 & Depleted \\
\hline Penaeus monodon & Giant tiger prawn & 447 & 1987 & 32 & 7.2 & Depleted \\
\hline Sunagocia indicus & Flathead & 2661 & 1987 & 131 & 4.9 & Collapsed \\
\hline Arius sp. & Catfish & 10,807 & 1976 & 516 & 4.8 & Collapsed \\
\hline Carcharhinus sp. & Blacktip shark & 4354 & 1972 & 111 & 2.6 & Collapsed \\
\hline
\end{tabular}

times. Some of the species have reached the collapsed status in the fishery and have again regained the abundant or less abundant status. Oil sardine (Sardinella longiceps) and Indian mackerel (Rastrelliger kanagurta) are the main-stay in Karnataka's marine fisheries and these species show high fluctuation in catch status cycling between abundant and depleted every 10-20 years (Figure 2a,b). Black pomfret (Parastromateus niger) and silver pomfret (Pampus argenteus) have been highly fluctuating and are currently in the less abundant and abundant status respectively (Figure $2 c$ ). The tuna Kawakawa developed as a fishery after 1973 and it is in the less abundant status currently (Figure $2 d$ ). Fishing for shrimp resources (Figure $2 e$ ) was developed after 1972 and the kadal shrimp (Metapenaeus dobsoni) collapsed once and regained abundant status 3 times over the years. The crab fishery developed after 1985 showed fluctuation in catch status and Portunus pelagicus, the blue crab (Figure $2 f$ ) is in the less 







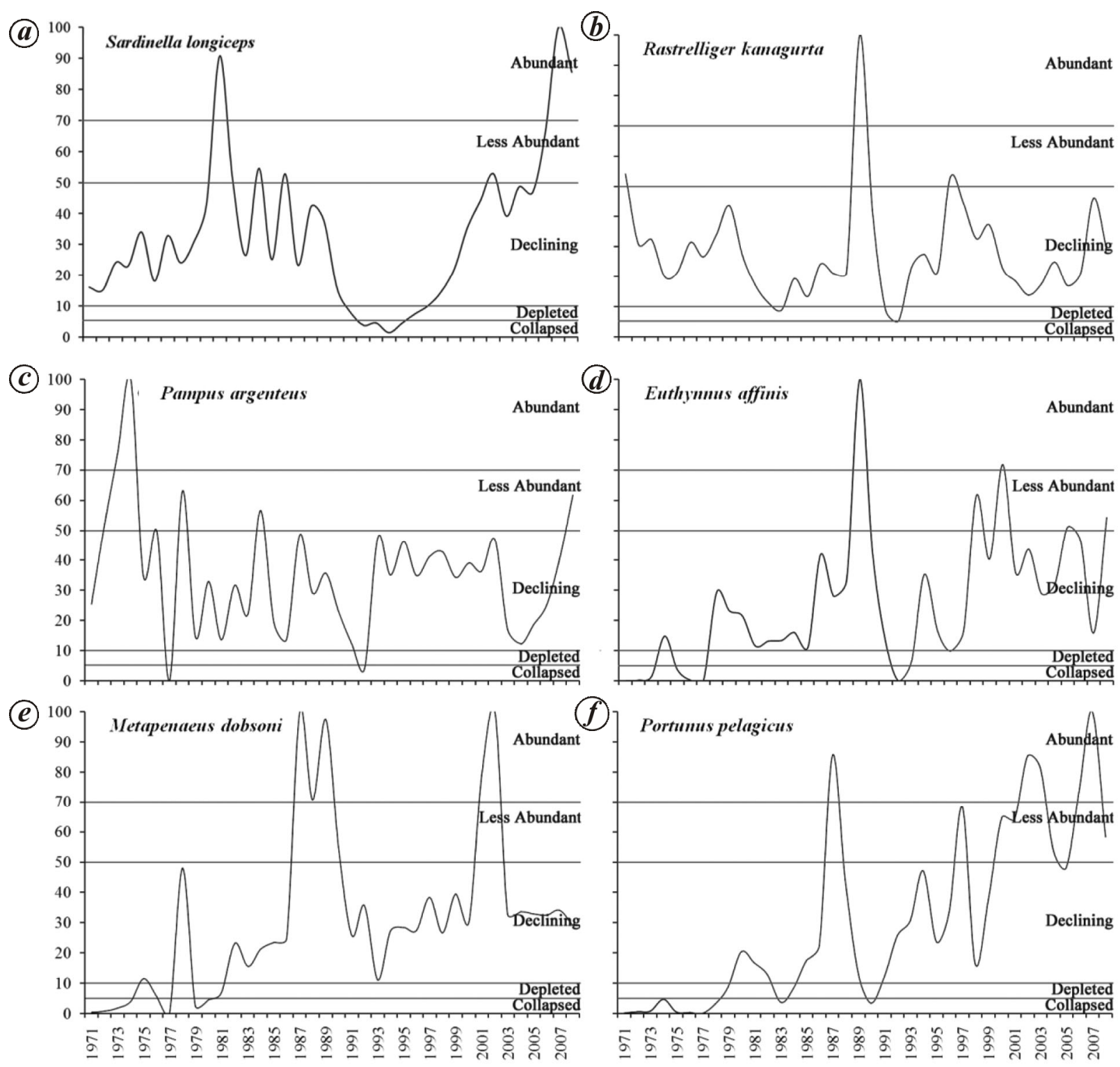

Figure 2. Time series of stock status of selected six species classified in the fluctuating status.

abundant status currently. Almost all the species in this category have fast growth rates and r-selected reproductive strategy (Table 2), except for the stingray Himantura $\mathrm{sp}$.

The species under the developing group are shown in Table 2 and Figure 3. These are the fish stocks whose status has continuously improved over the years. Here, the depleted/collapsed status in the earlier years does not point to actual depletion and in fact indicates the developing status of the fishery. Of the 10 species in this category, 9 have fast growth and 8 have r-selected reproductive strategies. Two cephalopods have fast growth and are k-selected.

The species under the dwindling group were catfish (Arius sp.), queenfish (Scomberoides sp.), spadenose shark (Scoliodon laticaudus), blacktip shark Car- charhinus sp., anchovy (Stolephorus sp.), Dussumier's anchovy (Thryssa dussumieri), white sardine (Escaulosa thoracata), scads (Caranx sp.), giant tiger prawn (Penaeus monodon), speckled shrimp (Metapenaeus monoceros), kiddi shrimp (Parapenaeopsis stylifera), flathead (Sunagocia indicus), Indian white prawn (Fenneropenaeus indicus), spotted seerfish (Scomberomorus guttatus) and mantis shrimp (Miyakea nepa) (Table 2 and Figure 4). Two of the collapsed species and one declining species in this category have slow growth and are $\mathrm{k}$-selected. The remaining 12 species have fast growth and have r-selected reproductive strategy.

Catfish which is an important mid-water resource is currently in the depleted status after collapse of the fishery in 1992 (Figure 4a). Spotted seerfish which was in abundant status once during 1981 is seen in declining 




Figure 3. Time series of stock status of six species classified in the developing status.

status (Figure $4 b$ ). Among the sharks, Spadenose shark fishery has declined after 1990 and the Blacktip sharkwhich showed abundant status for 3 years (1971-1973) has collapsed and is yet to recover (Figure $4 e$ ). The flathead fishery developed after 1981 and showed fluctuation but declined in fishery after 2002 and is in the collapsed status currently (Figure $4 d$ ). The giant tiger prawn (Figure $4 f$ ), speckled shrimp, kiddi shrimp are all grouped in the declining status currently.

The species which had depleted/collapsed and recovered to abundant/less abundant status, during the study period along with the number of years it took for their recovery is shown in Table 3. According to this, 32 species were in depleted or collapsed status at least once during the 37 years of study. Most of them (21 species) took short duration of 1-5 years for recovery whereas 7 species (oil sardine, Indian mackerel, kadal shrimp, pony- fishes, chacunda gizzard shad, flathead and giant tiger prawn) took 6-10 years for recovery. Blacktip shark, speckled shrimp and mantis shrimp took a longer period of more than 10 years for recovery whereas the catfish had recovered once after 9 years and after the collapse in 1992 it is yet to recover ( $>20$ years).

When these stocks were grouped into taxonomic families, it showed that the Stromatidae, Loliginidae and Hemiramphidae families took the shortest time averaging 1 year to recover (Figure 5). Eleven families were observed to recover in $1-5$ years whereas 4 families took 6-10 years to recover. The remaining 3 families Squillidae, Carcharinidae and Ariidae took longer time to recover, i.e. 12, 14 and 16 years respectively (Figure 5).

The trend in non-standardized aggregate annual fishing effort is shown in Figure 6. In 1971, the aggregate effort was a little more than a quarter million hours and it grew 
(a)

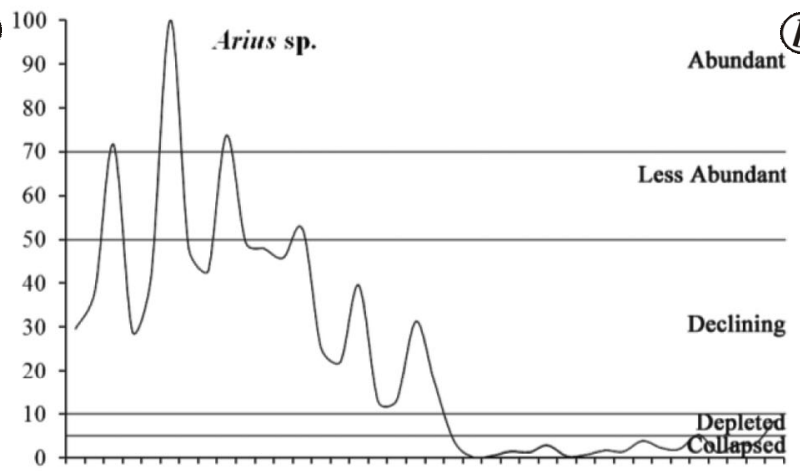

(c)
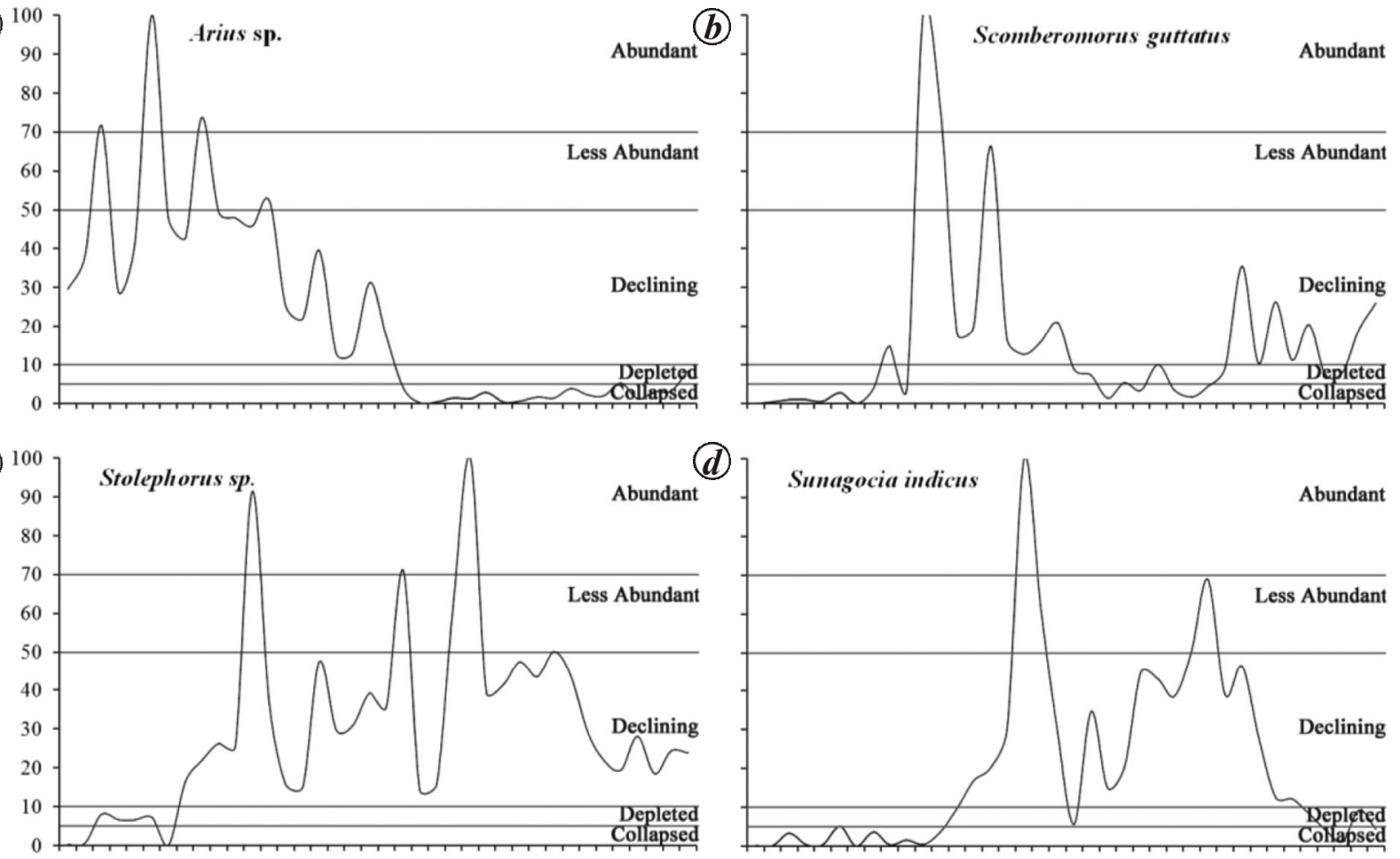

(d)

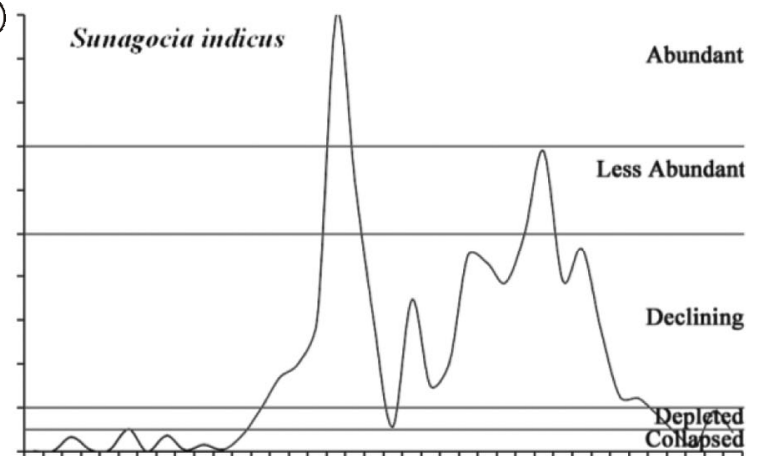

(e)

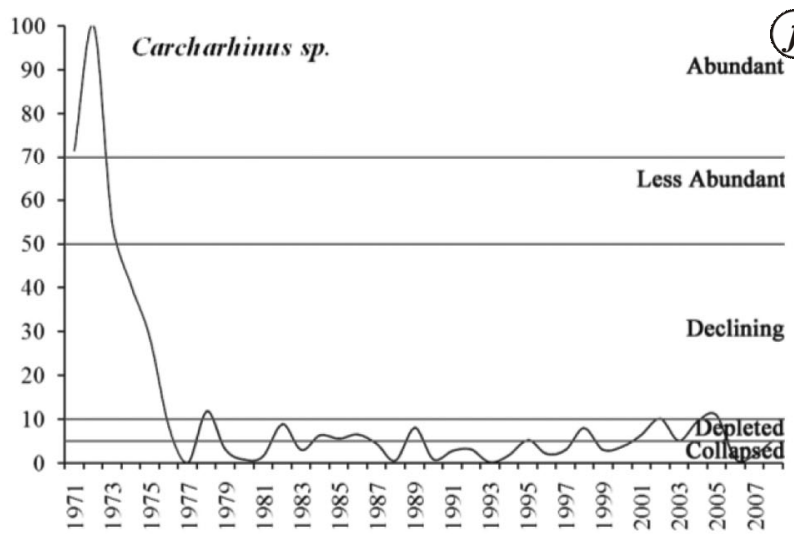

(f)

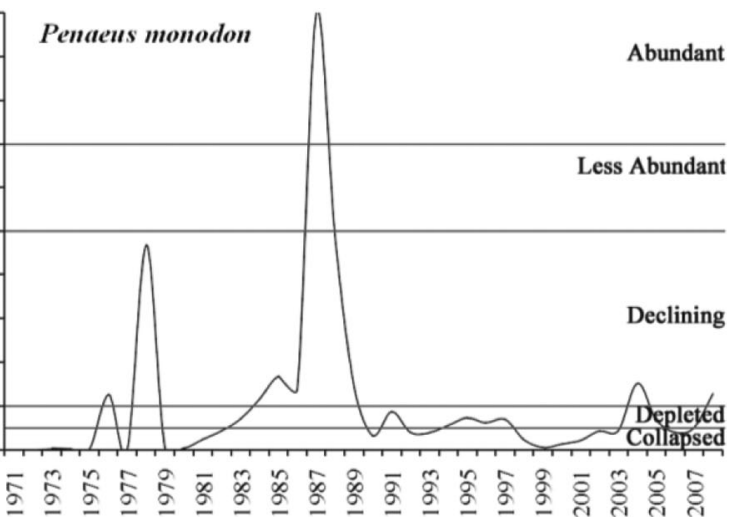

Figure 4. Time series of stock status of selected six species classified in the dwindling status.

more than 20-times to nearly 6 million hours in 2008 . There was a significant dip in effort during the early nineties, otherwise, effort showed consistent increase with minor dips.

\section{Discussion}

Analysis of the stock status showed that in 2008 the maximum numbers of species/stocks were in the declining group $(53 \%)$ and there were only two depleted stocks; white sardine (Escualosa thoracata) and giant tiger prawn (Penaeus monodon). Three stocks, flathead (Sunagociaindicus), catfish (Arius sp.) and blacktip shark (Carcharhinus sp.) were in collapsed status. These results compare well with those of Mohamed et al. ${ }^{22}$ who studied 19 species from Kerala and 22 species from Karnataka and concluded that the maximum of $47 \%$ were in declining status. George and Abowei ${ }^{32}$ state that a decline status may or may not indicate risk of extinction at the population level. But at the ecosystem level, the decline of an abundant species may represent a massive biomass loss which may be of greater concern ${ }^{33,34}$, than the loss of a small number of individuals of a rare species. Global records over the past millennium revealed a rapid decline of native species diversity since the onset of industrialization due to fishing ${ }^{35}$. Using a different criteria, they ${ }^{35}$ noted that $29 \%$ of globally fished species were considered collapsed whereas in our study only $6 \%$ of the commonly fished taxa were under the collapsed category.

The stock status indicator when expanded to a time series was able to reveal how stocks changed from one status to another over time. The method also helped to 


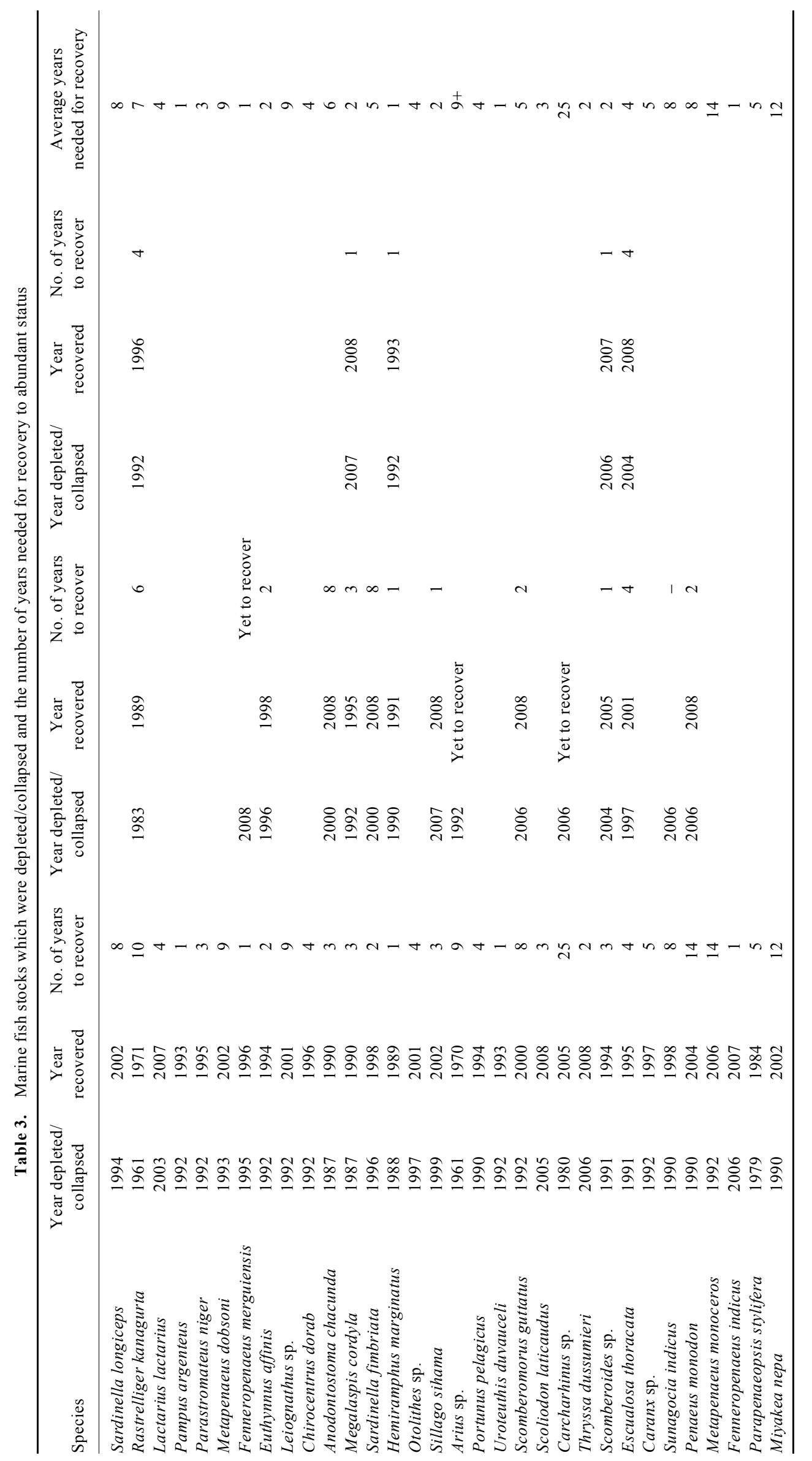


categorize stocks on the basis of their change in status over time. Majority of stocks (22 out of 47) were those which showed wide fluctuations in catch irrespective of continuously increasing fishing efforts. These stocks, mostly small pelagics and small and medium demersals, moved between declining to abundant status rapidly in spite of increasing effort. In some cases, the change was within 2 years, and in no case it was more than 3-4 years. For example, the Indian mackerel, $R$. kanagurta was in the depleted status in 1983 and moved up to an all-time high abundant status within 6 years and again reached depleted status in 1993 within 4 years. This indicates the inherent resilience of these stocks to fishing pressure and/or the environmental influences on their recruitment to the fishery. A recent global study on resilience and recovery of overexploited marine fish populations mainly of the temperate region shows that majority of the stocks are resilient to moderate overfishing and have a good chance of recovery within 10 years if fishing pressure is reduced substantially ${ }^{36}$. In spite of the limitations of this study, in the tropics, the fluctuation in abundance of these stocks in the absence of reduced efforts appears to be a function of their inherent biological capacities ${ }^{37}$ such



Figure 5. Number of years needed for recovery of different taxonomic families of depleted/collapsed stocks.

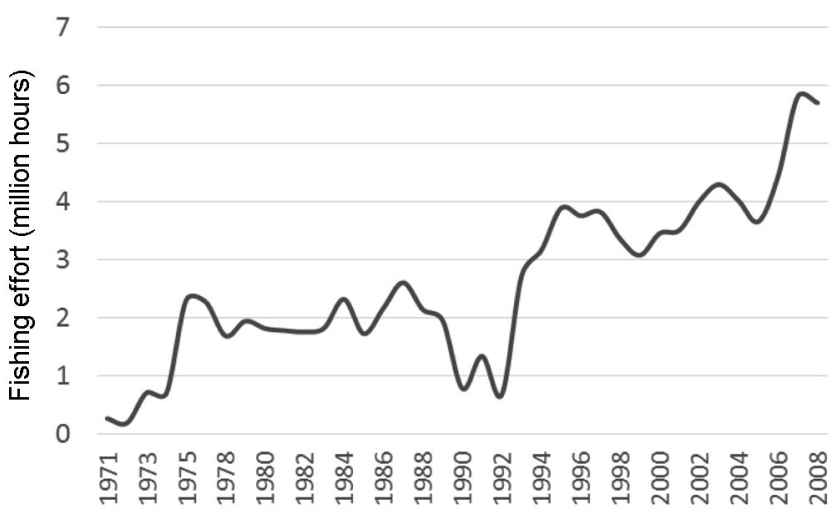

Figure 6. Annual trend in non-standardized aggregated annual fishing effort from all gears in Karnataka. as fast growth, high fecundity and speedy regeneration times.

The 15 stocks identified as dwindling included the large, slow-growing predators such as catfish, sharks and queen fish, and highly targeted, but fast growing shrimp stocks such as tiger and speckled shrimp. Habitat assessment showed that most of the species ( 9 out of 15) in this category were demersals or bentho-pelagics exploited by trawls, pointing to the non-selective, destructive nature of the trawl gear. Most of these stocks have had exceptionally high abundances during the 37-year-study period and are now in declining, depleted or collapsed status. For instance, the tiger shrimp, $P$. monodon was abundant in 1987 and thereafter, the stock collapsed in 1990 after which recovery has been slow. All of them, with the exception of carcharhinid sharks and shrimps, have recovered during this period. Hutchings ${ }^{12}$ stated that there is very little evidence for rapid recovery from prolonged declines, in contrast to the perception that marine fishes are highly resilient to large population declines ${ }^{38}$. Our study points to the high regenerative capacities of tropical fish stocks in general. The numbers of fish stocks categorized as developing were comparatively few (10 out of 47). This is keeping with the global trend where only few fish stocks are in the less-exploited status $(\sim 10 \%)^{39}$.

Indian maritime states are characterized by the absence of an objective oriented fisheries management regime. The only broad regulation that is followed is the ban on mechanized fishing for a period of 47 days every year. In temperate waters, studies have found that marine resource exploitation can deplete stocks faster than regulatory agencies can respond ${ }^{40}$. A caveat of the present study is that the assessments are made from estimated catch trends and not from biomass assessments. The catch trends showed that most species $(66 \%)$ had fast recovery capacity within 1-5 years whereas $9 \%$ were slow to recover. The exceptions were the blacktip shark which had just started recovering after 25 years of collapse and the catfish which had also started recovering after 20 years. Worm et al. $^{35}$ in their global assessment noted that rates of recovery were positively correlated with fish diversity as enhanced recovery was noted when fishers switch more readily among target species, potentially providing overfished taxa with a chance to recover. In temperate waters, there is only limited evidence for recovery of depleted fisheries based on the present management strategies employed $^{12,41}$. Most severely overfished stocks hence tend to stay depressed or recover only slowly; exceptions to this rule mostly concern particular fast-growing species such as herring and sardines ${ }^{42}$ and certain stocks of cod which are well managed ${ }^{43}$. The most important point to be noted is that currently there is no ability to engineer fast recovery of marine resources under the fisheries management regulations in vogue ${ }^{42}$. Sathianandan et al. ${ }^{23}$ showed that catfish which is collapsed in Karnataka and Kerala $^{22}$ come under abundant status mainly due to the 
high catches from other states or in other words, a wider spatial footprint. In Karnataka, during 2008, it was seen that the fishery of this species has improved from collapsed to depleted status, showing signs of recovery after 20 years.

Average time for recovery of the families Ariidae and Carcharhinidae was observed to be 16 and 12 years respectively, which is comparatively slow. The family Squillidae which, in recent years forms a major component of fish meal, was noted to recover in 12 years and this needs to be carefully monitored. Stock recovery times of documented finfish and invertebrate ranged from 3 to 30 years, with demersal recoveries generally being longer than pelagic ones ${ }^{44}$. Clupeids, such as herring and sardines, have shown more rapid recovery within 5-10 years after depletion, whereas gadoids showed no, or slow, recovery within 15 years after depletion ${ }^{41}$. It has been shown that $95 \%$ of recoveries of exploited marine species in estuarine and coastal regions were enabled by reduced or banned exploitation; $72 \%$ by habitat protection, especially of breeding colonies and feeding grounds; and $8 \%$ by pollution controls ${ }^{45,46}$. In most cases $(78 \%)$, these measures were most successful when implemented in combination ${ }^{14}$. For locally extirpated species, assisted re-introduction has enabled some successful re-establishments of wild populations ${ }^{47,48}$. However the recoveries observed in the present study are those which have happened with limited management or regulations and no targeted reductions in effort.

In India, recent stock assessment of exploited fisheries has indicated that most fish stocks are being exploited close to maximum sustainable yield level, many overexploited and few underexploited ${ }^{49,50}$. For many of the local, small, tropical, short-lived species, short-term fluctuations are not significant, even if it is caused by excessive fishing pressure. The depleted and declining stocks (particularly those close to the threshold of depleted status) need to be carefully monitored and their conservation and rebuilding plans need to be made. As a first step for rebuilding stocks, fishing effort has to be reduced and strict implementation of the legal mesh sizes and net dimensions would particularly help in preventing growth of overfishing and help in restoration of stocks. As a developing country with multiple stakeholder compulsions, India has found it difficult to implement basic fisheries management principles. It is clear that small and shortlived species could recover fast but in the case of large and long-lived species such as the catfish and blacktip shark, it is more than 20 and 25 years since the species has collapsed. The catfish stocks are improving in recent years, and care must be taken to see that recruitment overfishing is not allowed to happen again by restricting its capture during the breeding period by seiners. The most obvious drivers of recovery are the reduction of those human impacts that caused the depletion or degradation in the first place ${ }^{14}$.
1. Carlton, J. T., Geller, J. B., Reaka-Kudla, M. L. and Norse, E. A., Historical extinctions in the sea. Ann. Rev. Ecol. Syst., 1999, 30, 525-538.

2. Roberts, C. M. and Hawkins, J. P., Extinction risk in the sea. Trends Ecol. Evol., 1999, 14, 241-246.

3. Dulvy, N. K., Sadovy, Y. and Reynolds, J. D., Extinction vulnerability in marine populations. Fish Fish., 2003, 4, 24-64.

4. Tickell, C., Foreword: the value of diversity. In Marine Biodiversity. Patterns and Processes (ed. Ormond, R. F. G.), Cambridge University Press, 1999, pp. xiii-xxii.

5. Berkes, F., Mahon, R., Mcconney, P., Pollnac, R. and Pomeroy, R., Managing Small-Scale Fisheries: Alternative Directions and Methods, International Development Research Centre, Ottawa, IDRC, 2001, pp. 320.

6. Davy, B., Foreword. In Managing Small-scale Fisheries (eds Berkes, F. et al.), IDRC-CRDI, Ottawa, 2000, pp. vii-viii.

7. Purvis, A., Jones, K. E. and Mace, G. M., Extinction. Bioessays, 2000, 22, 1123-1133.

8. Rosenzweig, M. L., Species Diversity in Space and Time, Cambridge University Press, Cambridge, 1995, p. 460.

9. Verberk, W., Explaining general patterns in species abundance and distributions. Nature Education Knowledge, 2012, 3(2), $1-5$.

10. Salit, R., Fish stocks 'can recover,' marine expert says at URI lecture. In Breaking News, providencejournal.com, Providence J., 12 June 2013; http://www.providencejournal.com/breaking-news/ content/20130612-fish-stocks-can-recover-marine-expert-says-aturi-lecture.ece (accessed on 17 April 2014).

11. Jensen, O. P., Rethinking the global fisheries crisis. In 2013 Annual Public Lecture Series, Scientists and Journalists: Getting the Point Across, 10-14 June 2013; Coastal Institute on Narragansett Bay, Auditorium University of Rhode Island, Graduate School of Oceanography, Narragansett, 2013; http://metcalfinstitute.org/ lectures/olaf-jensen/

12. Hutchings, J. A., Collapse and recovery of marine fishes. Nature, 2000, 406, 882-885.

13. Desjardins, L., Fish stocks may recover if fishing stopped soon enough, study shows; http://www.rcinet.ca/en/2013/04/19/fishstocks-may-recover-if-fishing-stopped-soon-enough-study-shows/, Friday 19 April 2013.

14. Lotze, H. K., Coll, M., Magera, A. M., Ward-Paige, C. and Airoldi, L., Recovery of marine animal populations and ecosystems. Trends Ecol. Evol., 2011, 26(11), 595-605.

15. Rosenberg, A. A., Swasey, J. H. and Bowman, M., Rebuilding US fisheries: progress and problems. Front. Ecol. Environ., 2006, 4, 303-308.

16. Worm, B. et al., Rebuilding global fisheries. Science, 2009, 325(5940), 578-585.

17. CNN, Fish stocks can recover if well managed, says study, 2009; http://edition.cnn.com/2009/TECH/science/07/30/conservation. fish/index.html?iref=24hours, CNN.com (accessed on 17 April 2014).

18. Pillai, N. G. K. and Katiha, P. K., Evolution of Fisheries and Aquaculture in India, Central Marine Fisheries Research Institute, Kochi, 2004, p. 240.

19. Srinath, M. and Pillai, N. G. K., Marine fisheries of India: an approach to responsible fisheries management. Fishing Chimes, 2006, 26(4), 23-28.

20. Zacharia, P. U., Krishnakumar, P. K., Muthiah, C., Krishnan, A. A. and Durgekar, R. N., Assessment of bycatch and discards associated with bottom trawling along Karnataka coast, India. In Sustain Fish (eds Kurup, B. M. and Ravindran, K.), CUSAT, Kochi, India, 2006, pp. 434-445.

21. Pramod, G., Illegal, unreported and unregulated marine fish catches in the Indian Exclusive Economic Zone, Field report, Policy and Ecosystem Restoration in Fisheries, Fisheries Centre, 


\section{RESEARCH ACCOUNT}

University of British Columbia, BC, Vancouver, Canada, 2010 pp. 30; http://www.mrag.co.uk/Documents/IUU_India.pdf

22. Mohamed, K. S. et al., Depleted and collapsed marine fish stocks along southwest coast of India - a simple criterion to assess the status. In Coastal Fishery Resources of India, Conservation and Sustainable Utilisation (eds Meenakumari, B. et al.), Society of Fisheries Technologists, Kochi, India, 2010, pp. 67-76.

23. Sathianandan, T. V., Jayasankar, J., Kuriakose, S., Mini, K. G. and Mathew, W. T., Indian marine fishery resources: optimistic present, challenging future. Indian J. Fish., 2011, 58(4), 1-15.

24. Pillai, N. G. K. and Ganga, U., Sustainable management of marine fisheries of the Exclusive Economic Zone of India. In Coastal Fishery Resources of India, Conservation and Sustainable Utilisation (eds Meenakumari, B. et al.), Society of Fisheries Technologists, Kochi, India, 2010, pp. 14-38.

25. McClanahan, T. R. and Humphries, A. T., Differential and slow life-history responses of fishes to coral reef closures. Mar. Ecol. Prog. Ser., 2012, 469, 121-131.

26. Mohamed, K. S., Muthiah, C., Zacharia, P. U., Sukumaran, K. K., Rohit, P. and Krishnakumar, P. K., Marine Fisheries of Karnataka state, India. Naga, ICLARM Quart., 1998, 21(2), 10-15.

27. Mohamed, K. S., Zacharia, P. U., Rohit, P., Kemparaju, S., Purandhara, C. and Lingappa, Y., Major and minor fisheries harbours of India 3. The fisheries harbours and fishery in south Karnataka. Mar. Fish. Infor. Serv. T\&E Ser., 1998b, 153, 8-15.

28. CMFRI, Trends in total marine fish production in India - 1978 Mar. Fish. Infor. Serv. T\&E Ser., 1979, 9, 7-22.

29. Srinath, M., Kuriakose, S., Ammini, P. L., Prasad, C. J., Ramani, K. and Beena, M. R., Marine Fish Landings in India 1985-2004, Estimates and Trends, Central Marine Fisheries Research Institute, Spl. Publ., Kochi, India, 2006, vol. 89, p. 166.

30. CMFRI, Annual Report 2013-14, Central Marine Fisheries Research Institute, Kochi, India, 2014, p. 274.

31. Srinath, M., Kuriakose, S. and Mini, K. G., Methodology for Estimation of Marine Fish Landings in India, Central Marine Fisheries Research Institute, Spl. Publ., Kochi, India, 2005, vol. 86, p. 57.

32. George, A. D. I. and Abowei, J. F. N., The composition, ranking and diversity of Callinectes amnicola (De Rochebrune, 1883) food from Okpoka Creek, Niger Delta, Nigeria. Adv. J. Food Sci. Technol., 2009, 1(1), 12-18.

33. Bellwood, D. R., Hoey, A. S. and Choat, J. H., Limited functional redundancy in high diversity systems: resilience and ecosystem function on coral reefs. Ecol. Lett., 2003, 6, 281-285.

34. Dulvy, N. K., Freckleton, R. P. and Polunin, N. V. C., Coral reef cascades and the indirect effects of predator removal by exploitation. Ecol. Lett., 2004, 7, 410-416.

35. Worm, B. et al., Impacts of biodiversity loss on ocean ecosystem services. Science, 2006, 314, 787-790.

36. Neubauer, P., Jensen, O. P., Hutchings, J. A. and Baum, J. K., Resilience and recovery of overexploited marine populations. Science, 2013, 340, 347-349.

37. Vivekanandan, E., Mohamed, K. S., Kuriakose, S., Sathianandan, T. V., Ganga, U., Pillai, S. L. and Nair, R. J., Status of marine fish stock assessment in India and development of a sustainability index. In 2nd Workshop on the Assessment of Fishery Stock
Status in the South and Southeast Asia, 5-9 October 2009 Bangkok, Thailand.

38. Musick, J. A., Criteria to define extinction risk in marine fishes. Fisheries, 1999, 24, 6-12.

39. FAO, The state of world fisheries and aquaculture 2008. In Food and Agriculture Organization of the United Nations, Fisheries and Aquaculture Department, Rome, 2009, p. 176.

40. Berkes, F. et al., Globalization, roving bandits, and marine resources. Science, 2006, 311, 1557-1558.

41. Hutchings, J. A. and Reynolds, J. D., Marine fish population collapses: consequences for recovery and extinction risk. BioScience, 2004, 54, 297-309.

42. Worm, B. and Vanderzwaag, D., High-seas fisheries: Troubled waters, tangled governance, and recovery prospects. In Behind the Headlines, Canadian Institute of International Affairs, The Centre for International Governance Innovation, 2007, 64(5), 32.

43. Eero, M., Vinther, M., Haslob, H., Huwer, B., Casini, M., StorrPaulsen, M. and Köster, F., Spatial management of marine resources can enhance the recovery of predators and avoid local depletion of forage fish. Conserv. Lett., 2012, 5(6), 486-492.

44. Caddy, J. F. and Agnew, D. J., An overview of recent global experience with recovery plans for depleted marine resources and suggested guidelines for recovery planning. Rev. Fish Biol. Fish., 2004, 14, 43-112.

45. Lotze, H. K. et al., Depletion, degradation, and recovery potential of estuaries and coastal seas. Science, 2006, 312, 1806-1809.

46. Lotze, H. K., Historical reconstruction of human-induced changes in US estuaries. Oceanogr. Mar. Biol. Annu. Rev., 2010, 48, $267-$ 338 .

47. Gregr, E. J., Nichol, L. M., Watson, J. C., Ford, J. K. B. and Ellis, G. M., Estimating carrying capacity for sea otters in British Columbia. J. Wildl. Manage., 2008, 72(2), 382-388.

48. Lotze, H. K. and Milewski, I., Two centuries of multiple human impacts and successive changes in a North Atlantic food web. Ecol. Appl., 2004, 14, 1428-1447.

49. Modayil, M. J. and Jayaprakash, A. A., Status of Exploited Marine Fishery Resources of India, Central Marine Fisheries Research Institute, Kochi, India, 2003, p. 308.

50. Pillai, N. G. K., Pelagic fisheries of India. In Handbook of Fisheries and Aquaculture, ICAR, New Delhi, 2006, pp. 56-77.

ACKNOWLEDGEMENTS. We thank the Director, CMFRI for providing the necessary facilities and infrastructure to carry out the work. We also thank Dr T. V. Sathianandan, Head, FRAD, CMFRI for providing the catch data and statistics to carry out the work. Comments provided by two anonymous reviewers greatly helped improve the manuscript. We acknowledge the financial assistance from the AP Cess Fund of Indian Council of Agricultural Research, New Delhi.

Received 16 December 2014; revised accepted 29 November 2015

doi: $10.18520 / \mathrm{cs} / \mathrm{v} 110 / \mathrm{i} 4 / 584-594$ 